\title{
Bioprocessing of "Hair Waste" by Paecilomyces lilacinus as a Source of a Bleach-Stable, Alkaline, and Thermostable Keratinase with Potential Application as a Laundry Detergent Additive: Characterization and Wash Performance Analysis
}

\author{
Ivana A. Cavello, Roque A. Hours, and Sebastián F. Cavalitto \\ Research and Development Center for Industrial Fermentations (CINDEFI) (UNLP, CONICET La Plata), Calle 47 y 115, \\ B1900ASH La Plata, Argentina \\ Correspondence should be addressed to Sebastián F. Cavalitto, cavali@biotec.org.ar
}

Received 6 September 2012; Accepted 20 November 2012

Academic Editor: Michael Hust

Copyright ( $) 2012$ Ivana A. Cavello et al. This is an open access article distributed under the Creative Commons Attribution License, which permits unrestricted use, distribution, and reproduction in any medium, provided the original work is properly cited.

\begin{abstract}
Paecilomyces lilacinus (Thom) Samson LPS 876, a locally isolated fungal strain, was grown on minimal mineral medium containing "hair waste," a residue from the hair-saving unhairing process, and produced a protease with keratinolytic activity. This enzyme was biochemically characterized. The optimum reaction conditions, determined with a response surface methodology, were $60^{\circ} \mathrm{C}$ and $\mathrm{pH}$ 6.0. It was remarkably stable in a wide range of $\mathrm{pHs}$ and temperatures. Addition of $\mathrm{Ca}^{2+}, \mathrm{Mg}^{2+}$, or sorbitol was found to be effective in increasing thermal stability of the protease. PMSF and $\mathrm{Hg}^{2+}$ inhibited the proteolytic activity indicating the presence of a thiol-dependent serine protease. It showed high stability toward surfactants, bleaching agents, and solvents. It was also compatible with commercial detergents $(7 \mathrm{mg} / \mathrm{mL})$ such as Ariel, Skip, Drive, and Ace, retaining more than $70 \%$ of its proteolytic activity in all detergents after $1 \mathrm{~h}$ of incubation at $40^{\circ} \mathrm{C}$. Wash performance analysis revealed that this protease could effectively remove blood stains. From these properties, this enzyme may be considered as a potential candidate for future use in biotechnological processes, as well as in the formulation of laundry detergents.
\end{abstract}

\section{Introduction}

Microbial proteases are the most widely exploited industrial enzymes with major application in detergent formulations $[1,2]$. These enzymes are being widely used in detergent industry since their introduction in 1914 as detergent additive. Over the past 30 years, the importance of proteases in detergents has changed from being the minor additives to being the key ingredients. The main areas where use of proteases has expanded are household laundry, automatic dishwashers, and industrial and institutional cleaning. In laundry detergents, protein stains such as grass, blood, food, and human swear, are removed through proteolysis. The performance of proteases is influenced by several factors such as $\mathrm{pH}$ of detergent, ionic strength, wash temperature, detergent composition, bleach systems, and mechanical handling. Thus, the key challenge for the use of enzymes in detergents is their stability. Various attempts have been made to enhance stability of alkaline proteases by sitedirected mutagenesis [3] and protein engineering. "Subtilisin Carlsberg" has been protein engineered to obtain a bleachstable, alkaline protease by molecular modification [4], but still, there is always a need for newer thermostable alkaline proteases which can withstand bleaching agents present in detergent. Among these different proteases, keratinases constitute a group of enzymes capable of disrupting the highly stable keratin structure consisting of disulfide, hydrogen, and hydrophobic bonds in the form of $\alpha$-helices and $\beta$-sheets [5].

Argentine's economy has traditionally been based on agriculture and related industries. Livestock (cattle, sheep, and poultry) and grains have long been the bulwark of its wealth; its cattle herds are among the world's finest. There 
are more than 50 million of livestock which generate large amounts of waste including insoluble keratin-containing animal material such as feather, hair, wool, nails claws, hooves, horns, and beaks.

Although hair-saving unhairing processes reduce the organic load from beamhouse liquid effluent, a new solid residue called "hair waste" is generated, its appropriate disposal being then necessary. In a hair saving unhairing process almost $10 \%$ (wet basis) in weight of each salted bovine hide become hair waste. Because of tanning industry in Argentina processes, on average, more than 100 ton of salted hide per day, more than 10 ton of solid waste are generated per day, generating an environmental problem of considerable magnitud [6]. Since it is a protein waste, it deserves special attention in order to be utilized for practical purposes.

The fungal biotransformation of the "hair waste" implies considering it as a raw material instead of the present idea of disposability. Thus, hair waste would be the substrate, on which the fungus would act, giving rise to a (partially) hydrolyzed protein with different potential uses (i.e., as animal feed, fertilizer, etc.). In addition, the fungus would produce a proteolytic (keratinolytic) extract of biotechnological interest with a variety of potential applications (cosmetics, textiles, detergent industries, etc.). This paper deals with a particularly case of the second aspect above mentioned.

A series of studies dealing with the bioconversion of keratin waste resulted in the discovery of a novel keratinase activity in a culture supernatant of a fungal strain (Paecilomyces lilacinus (Thom) Samson LPS 876) grown on chicken feather as a sole of carbon, nitrogen, and energy source [7]. In this paper, we report the biochemical characterization, including the effect of some surfactants and bleaching agents on enzyme stability, its compatibility with various commercial liquid and solid detergents and a study of an efficient stabilization method toward heat inactivation, of the keratinase produced by Paecilomyces lilacinus growing on hair waste substrate.

A wash performance was also done with particular emphasis on its potential application as an enzyme ingredient for the formulation of laundry detergents.

\section{Material and Methods}

2.1. Microorganism and Identification as a Keratinolytic Fungus. Paecilomyces lilacinus (Thom) Samson LPS 876, a nonpathogenic fungal strain locally isolated from alkaline forest soils, was used. It was selected from Spegazzini Institute Fungal Culture Collection (La Plata National University, Argentina) after a preliminary screening for keratinolytic fungal strains on feather meal agar containing (per liter) the following: defatted chicken feather meal, $15 \mathrm{~g}$; $\mathrm{NaCl}, 0.5 \mathrm{~g}$; $\mathrm{K}_{2} \mathrm{HPO}_{4}, 0.3 \mathrm{~g} ; \mathrm{KH}_{2} \mathrm{PO}_{4}, 0.4 \mathrm{~g}$; agar, $15 \mathrm{~g}$, pH 7.2. The strain selected was punctual streaked and incubated at $28^{\circ} \mathrm{C}$ for 15 days. The growth of the colony and the clear zone formation around it were daily studied. The ability to degrade keratin was determined according to the presence or absence of hydrolysis halo [8].
2.2. Culture Conditions and Enzyme Production. Production of protease by $P$. lilacinus was carried out in a minimal mineral medium containing (per liter) the following: $10 \mathrm{~g}$ hair waste, $0.496 \mathrm{~g} \mathrm{NaH} \mathrm{PO}_{4}, 2.486 \mathrm{~g} \mathrm{~K} \mathrm{~K}_{2} \mathrm{HPO}_{4}, 0.016 \mathrm{~g}$ $\mathrm{FeCl}_{3} \cdot 6 \mathrm{H}_{2} \mathrm{O}, 0.013 \mathrm{~g} \mathrm{ZnCl}$, $0.010 \mathrm{~g} \mathrm{MgCl}_{2}$, and $0.11 \mathrm{mg}$ $\mathrm{CaCl}_{2}$. Hair waste, obtained from a local tannery, was washed extensively with tap water, dried at $60^{\circ} \mathrm{C}$ for 2 days, and then kept at room temperature until used. In all cultures, it was a sole carbon, nitrogen, and energy source. The $\mathrm{pH}$ was adjusted to 7.0 previous to sterilization [9]. Cultures were performed at $28^{\circ} \mathrm{C}$ and $200 \mathrm{rpm}$ for 10 days in an orbital shaker, in $500 \mathrm{~mL}$ Erlenmeyer flasks containing $200 \mathrm{~mL}$ of medium, inoculated with $2 \times 10^{6}$ conidia per mL. Samples of $5 \mathrm{~mL}$ were withdrawn at regular intervals, centrifuged $\left(3,000 \times \mathrm{g}, 10 \mathrm{~min}, 4^{\circ} \mathrm{C}\right)$, and the supernatant was used for $\mathrm{pH}$, protein content, and enzyme activities determinations.

2.3. Protein Determination. The protein content was determined by Bradford's method using bovine albumin fraction $\mathrm{V}$ (SIGMA) as a standard [10].

2.4. Protease Activity. Proteolytic activity was measured as described by Liggieri et al. [11] with some modifications. Reaction mixture containing $100 \mu \mathrm{L}$ of appropriately diluted enzyme preparation and $250 \mu \mathrm{L}$ of $1 \%(\mathrm{w} / \mathrm{v})$ azocasein solution in $0.1 \mathrm{M}$ Tris-HCl buffer ( $\mathrm{pH}$ : 9) was incubated for $30 \mathrm{~min}$ at $37^{\circ} \mathrm{C}$. Reaction was stopped by precipitation of the residual substrate with $1 \mathrm{~mL}$ of trichloroacetic acid (TCA, 10\%). The mixture was kept at room temperature for $15 \mathrm{~min}$ and then centrifuged at 3,000 $\times \mathrm{g}\left(10 \mathrm{~min}, 20^{\circ} \mathrm{C}\right)$. One $\mathrm{mL}$ of $1 \mathrm{M} \mathrm{NaOH}$ was added to $1 \mathrm{~mL}$ of the supernatant, and absorbance was measured at $440 \mathrm{~nm}$. Measurement was made in triplicate using a blank with a heat inactivated enzyme solution. One unit of proteolytic activity $\left(\mathrm{U}_{\mathrm{C}}\right)$ was defined as the amount of enzyme that, under test conditions, causes an increase of 0.1 units in the absorbance at $440 \mathrm{~nm}$ per minute. Azocasein was synthesized as described by Riffel et al. [12].

2.5. Keratinase Activity. Keratinolytic activity was assayed as described by Joshi et al. [13] with some modifications: $800 \mu \mathrm{L} 0.1 \mathrm{M}$ Tris- $\mathrm{HCl}$ buffer ( $\mathrm{pH}$ : 9) was added to $30 \mathrm{mg}$ of azokeratin, and mixture was stirred for $15 \mathrm{~min}$ at room temperature until the azokeratin was completely suspended. Appropriately diluted enzyme preparation $(100 \mu \mathrm{L})$ was added and incubated for $25 \mathrm{~min}$ at $37^{\circ} \mathrm{C}$ with individual magnetic stirring. Reaction was then stopped by the addition of $200 \mu \mathrm{L}$ of TCA $(10 \%)$ and centrifuged at $3,000 \times \mathrm{g}(10 \mathrm{~min}$, $\left.20^{\circ} \mathrm{C}\right)$. The absorbance of the supernatant was measured at $440 \mathrm{~nm}$. A blank was prepared using heat-inactivated enzyme preparation. One unit of keratinase activity $\left(\mathrm{U}_{\mathrm{K}}\right)$ was defined as the amount of enzyme that, under test conditions, causes an increase of 0.01 units in the absorbance at $440 \mathrm{~nm}$ per minute. Azokeratin was synthesized as described by Joshi et al. [13] using defatted feather meal as keratin source.

The relationship between keratinolytic and proteinolytic activity (called $\mathrm{K}: \mathrm{C}$ ratio) is widely used as a parameter for evaluation of the keratinolytic potential of proteases $[14,15]$. 
$\mathrm{K}: \mathrm{C}$ ratio of $P$. lilacinus' keratinase was compared with those of several commercial proteases such as proteinase- $\mathrm{K}$ (Promega), Alcamax (Cergen), and papain (FLUKA). Stock solutions of these commercial enzymes, in concentration of $1 \mathrm{mg} / \mathrm{mL}$, were prepared in distilled water. They were diluted adequately, and both enzyme activities (keratinase and protease) were determined as described above.

2.6. Biochemical Characterization. A supernatant of a 5-dayold culture was used as crude enzyme preparation for the biochemical characterization of the keratinases produced by P. lilacinus $\left(2.5 \mathrm{U}_{\mathrm{C}} / \mathrm{mL}\right)$. It is worth to mention that, for practical reasons, protease activity was used in our research to represent keratinase activity, since keratinolytic (azokeratin) and proteolytic (azocasein) activities are directly related [16], a fact that was also later confirmed for $P$. lilacinus keratinase (see below).

2.7. Effect of $p H$ and Temperature on Enzyme Stability and Activity. The effect of $\mathrm{pH}$ and temperature on enzyme activity and stability was studied using a Response Surface Methodology (RSM) based on the use of a matrix of experiments by which the simultaneous variations of the factors can be studied. Uniform shell design proposed by Doehlert was selected for design the response surface [17]. The main advantage of this procedure lies in the possibility of extending this uniform net in any direction and increasing the number of factors in the study. The real values of the independent variables were coded based on a linear functionality between codified $(Z)$ and actual values $(X)$ according to:

$$
X: \frac{Z * \Delta X}{\Delta Z}+X_{0}
$$

where $X_{0}$ is the real value of the central point and $\Delta X$ and $\Delta Z$ are the difference between the highest and lowest values of real and coded numbers, respectively.

Multiple regression analysis based on the least square method was performed using Mathcad 2001 software [17]. For both determinations, the central values (zero level) for the experimental designs were $\mathrm{pH} 7.5$ and temperature $40^{\circ} \mathrm{C}$.

The $\mathrm{pH}$ and thermal stability were evaluated incubating the enzyme preparation for $2 \mathrm{~h}$ at each chosen experimental condition. The residual protease activity was determined under standard conditions and expressed as percentage of residual activity relative to a control (measured at $0 \mathrm{~h}$ of incubation). Temperature varied between 20 and $60^{\circ} \mathrm{C}$ and $\mathrm{pH}$ between 3.0 and 12.0, using a mixture of buffers (Glicine, MES and Tris, $20 \mathrm{mM}$ each).

The protective effect of $\mathrm{CaCl}_{2}$ and $\mathrm{MgCl}_{2}(5 \mathrm{mM}$, each) and sorbitol $(10 \% \mathrm{w} / \mathrm{v})$ on heat inactivation was also studied. The crude enzyme was incubated at $50-60^{\circ} \mathrm{C}$ with and without the chemicals mentioned above, and residual enzyme activity was measured at regular intervals under standard assay conditions.
The effect of $\mathrm{pH}$ and temperature on enzyme activity was determined at each condition set by the Doehlert's design. In this case, temperature varied between 20 and $60^{\circ} \mathrm{C}$ and $\mathrm{pH}$ between 6.0 and 12.0 using the same mixture of buffers described above.

2.8. Effect of Inhibitors, Metal Ions, and Organic Solvents on Enzyme Activity. In order to investigate the effect of different inhibitors of proteases, metal ions, and organic solvents on enzyme activity, the crude enzyme was preincubated for $1 \mathrm{~h}$ at room temperature with different reagents. Residual enzyme activity was determined and expressed as percentage relative to a reaction control (no addition). The different reagents tested were phenylmethanesulphonyl fluoride (PMSF, $2 \mathrm{mM})$, iodoacetate $(10 \mathrm{mM})$, ethylenediaminetetraacetate (EDTA, $5 \mathrm{mM}), 1,10$-Phenantroline $(1 \mathrm{mM})$, and Pepstatin A $(100 \mu \mathrm{g} / \mathrm{mL}), \mathrm{Ca}^{2+}, \mathrm{Mg}^{2+}, \mathrm{Zn}^{2+}$, and $\mathrm{Hg}^{2+}(1 \mathrm{mM}$ each). The solvents tested were DMSO, ethanol, methanol, and isopropanol ( $1 \% \mathrm{v} / \mathrm{v}$ each).

\subsection{Effect of Surfactants and Bleaching Agents on Enzyme} Stability. The suitability of the crude protease of $P$. lilacinus as a detergent additive was determined by testing its stability in presence of some surfactants such as SDS (sodium dodecyl sulphate), Triton $\mathrm{X}-100$, and Tween 20 , and bleaching agents such as hydrogen peroxide $\left(\mathrm{H}_{2} \mathrm{O}_{2}\right)$ and sodium perborate. The crude protease was incubated with different concentrations of these additives for $1 \mathrm{~h}$ at room temperature $\left(22^{\circ} \mathrm{C}\right)$, and then the residual proteolytic activity was measured under standard conditions against a control without any additives, which was taken as $100 \%$.

2.10. Detergent Compatibility. The compatibility of the protease activity in crude extract with commercial solid and liquid laundry detergents (locally available) was also studied. The solid detergents tested were Ariel (Procter \& Gamble), Drive, Skip, and Ala matic (Unilever), and the liquid ones were Ace and Ariel (Procter \& Gamble); also a prewashed liquid named Mr Musculo (SC Johnson \& son) was tested.

Solid detergents were diluted in tap water to give a final concentration of $7 \mathrm{mg} / \mathrm{mL}$, and liquid detergents and prewashed were diluted 100-fold to simulate washing conditions [18]. The endogenous enzymes contained in laundry detergents were inactivated by heating the diluted detergents for $1 \mathrm{~h}$ at $65^{\circ} \mathrm{C}$ prior the addition of an aliquot of crude protease. The corresponding reactions mixture were incubated in each detergents mentioned above for $1 \mathrm{~h}$ at different temperatures $\left(30-50^{\circ} \mathrm{C}\right)$, and the remaining activities were determined under standard conditions. The enzyme activity of a control, incubated under the similar conditions without detergent, was taken as $100 \%$.

2.11. Evaluation of Washing Performance. Clean cotton cloth pieces $(2.5 \mathrm{~cm} \times 2.5 \mathrm{~cm})$ were soiled with blood: $100 \mu \mathrm{L}$ of blood without pretreatment was applied to cloth piece and then dried. The stained cloth pieces were subjected to wash treatments with commercial solid detergent (Skip, a solid detergent available in Argentineans' market) diluted 


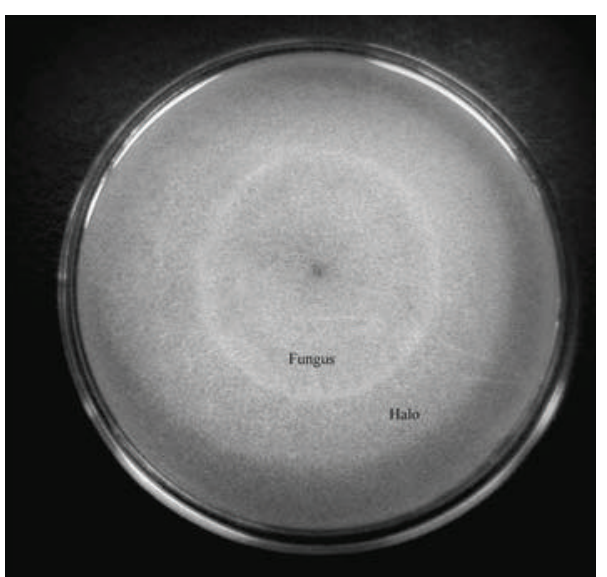

FIgURE 1: Qualitative test in feather meal agar plates for keratin degrading enzyme activity. A degradation halo surrounding the colony of $P$. lilacinus is observed.

in tap water at $7 \mathrm{mg} / \mathrm{mL}$, supplemented with and without crude enzyme. When the wash treatment was with the supplementation of the crude enzyme, endogenous enzymes contained in laundry detergents were inactivated by heating the diluted detergents for $1 \mathrm{~h}$ at $65^{\circ} \mathrm{C}$ prior to the addition of an aliquot of crude protease.

Two stained cloth pieces were taken in separate flasks, with $50 \mathrm{~mL}$ as final volume, as indicated above: flask with tape water, only, flask with tap water and commercial detergent at final concentration of $7 \mathrm{mg} / \mathrm{mL}$, and flask with tap water, commercial detergent, and crude enzyme of $P$. lilacinus $\left(62.5 \mathrm{U}_{\mathrm{C}} / 50 \mathrm{~mL}\right)$.

Each flask was incubated at two temperatures: 30 and $40^{\circ} \mathrm{C}$ for 30 and $60 \mathrm{~min}$ under agitation (200 rpm). After incubation, cloth pieces were taken out, rinsed with water, and dried. Visual examination of various pieces showed the effect of the crude enzyme in the removal of stains [19].

2.12. Statistical Analysis. All analyses were performed at least in triplicate, and data were expressed as means \pm standard deviations.

\section{Results and Discussion}

3.1. Identification of P. lilacinus as Keratinolytic Fungus. A series of fungal strains of the Spegazzini Institute Fungal Culture Collection (La Plata National University, Argentina) were preliminary screened for their keratinolytic potential using feather meal agar. In our case, P. lilacinus (Thom) Samson LPS 876 was selected because, after 15 days of incubation at $28^{\circ} \mathrm{C}$, a hydrolysis halo was observed indicating the keratinolytic capability of this strain (Figure 1). The use of this technique in a preliminary screening with a similar purpose was reported by Wawrzkiewicz et al. [20]. Where, among the 16 strains of dermatophytes tested, only Trichophyton verrucosum showed tiny fungal colonies surrounded by a wide clear zone of solubilized keratin.
3.2. Grow Profile of P. lilacinus on Hair Waste Medium. P. lilacinus LPS 876 grew well in a minimal mineral medium containing salts and hair waste as sole carbon, nitrogen, and energy source. As can be seen in Figure 2, extracellular enzyme activities (protease and keratinase) were associated with both an increment in soluble protein concentration as well as with a continuous increase in $\mathrm{pH}$ values in culture broth. These facts were reported by several authors for other microorganisms with high keratinolytic activity growing on this kind of substrates. The increment in $\mathrm{pH}$ value has been pointed out as an important indicator of the keratinolytic potential in microorganisms because of high level of deamination, with the concomitant ammonium accumulation in culture medium [21]. Moreover, Korniłłowicz-Kowlaska and Bohacz [22] concluded that substrate mass loss, a release of peptides and ammonia, sulfate excretion, and substrate alkalinization should be recognized as homogenized (due to mutual correlation) assessment parameters of the keratinolytic activity of fungi.

Enzyme activities were evaluated during the culture time course. Maximum protease and keratinase activities concurred at around 111-117 h of cultivation, (Figure 2). The ratio observed between both enzyme activities ( $\mathrm{K}: \mathrm{C}$ ratio) at different culture times was quite constant $(11.28 \pm$ 1.06). Therefore, the presence of a single enzyme responsible of both activities was tentatively postulated. Using the same enzyme assay conditions, it is assumed that a protease with $\mathrm{K}$ : C ratio higher than 5 is a true keratinase [23]. Generally, reported keratinases have a $\mathrm{K}: \mathrm{C}$ ratio ranged from 5 to 20 $[14,15,24]$.

The hydrolysis of azokeratin and azocasein by the proteases produced by $P$. lilacinus growing on hair waste was compared with commercial enzymes. The $\mathrm{K}: \mathrm{C}$ was chosen as criterion for enzyme specificity for keratinous substrates (Table 1). As can be seen, our crude enzyme preparation was superior for hydrolysis of keratin substrate compared with other commercially available proteases. Similar results were reported by Cheng et al. [25] for the keratinase of Bacillus licheniformis and by Gradišar et al. [14] for the keratinases of $P$. marquandii and Doratomyces microsporus.

3.3. Effect of $p H$ and Temperature on Enzyme Stability. In general, all detergent compatible enzymes are alkaline thermostable in nature with a high $\mathrm{pH}$ optima because the $\mathrm{pH}$ of laundry detergents is generally in the range of 9-12 and varying thermostability at laundry temperatures, $\left(50-60^{\circ} \mathrm{C}\right)$ [26-28]. For the study of the effect of $\mathrm{pH}$ and temperature a RSM was used. The $\mathrm{pH}$ and temperature values used in Doehlert's design for enzyme stability determination are shown in Table 2. The central point was replicated three times in order to determine the experimental error. Data presented in Table 2 were converted into second-order polynomial equation.

Statistical analysis of the results revealed that, in the range studied, the two variables, as well as their interactions, have a significant effect on protease (keratinase) stability.

The following regression equation was obtained to calculate the percentage of residual enzyme activity (\% R.A.) 


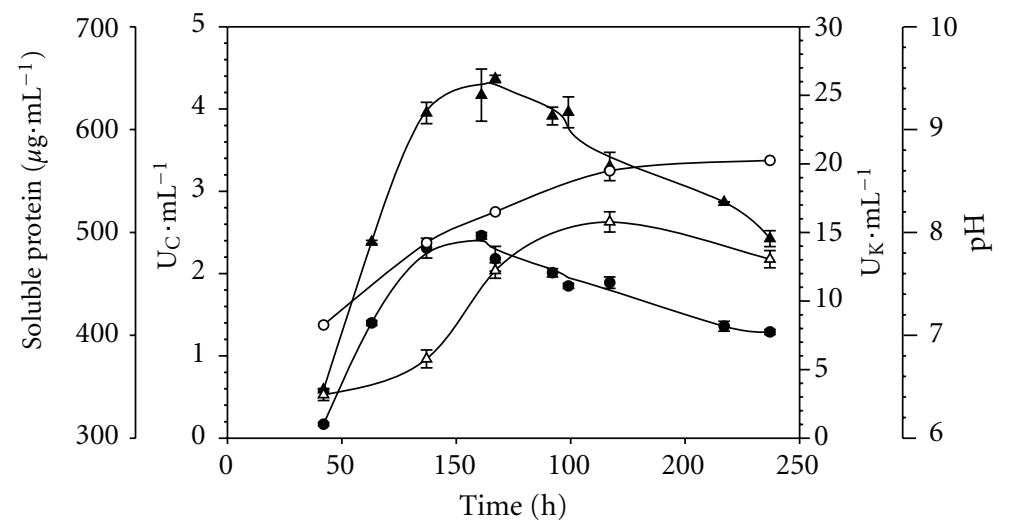

Figure 2: Time course of $P$. lilacinus culture using a minimal mineral medium containing $10 \mathrm{gL}^{-1}$ of hair waste (pH: 7). (•) proteolytic activity; $(\mathbf{\Lambda})$ keratinolytic activity; $(\triangle)$ soluble protein; $(\bigcirc) \mathrm{pH}$.

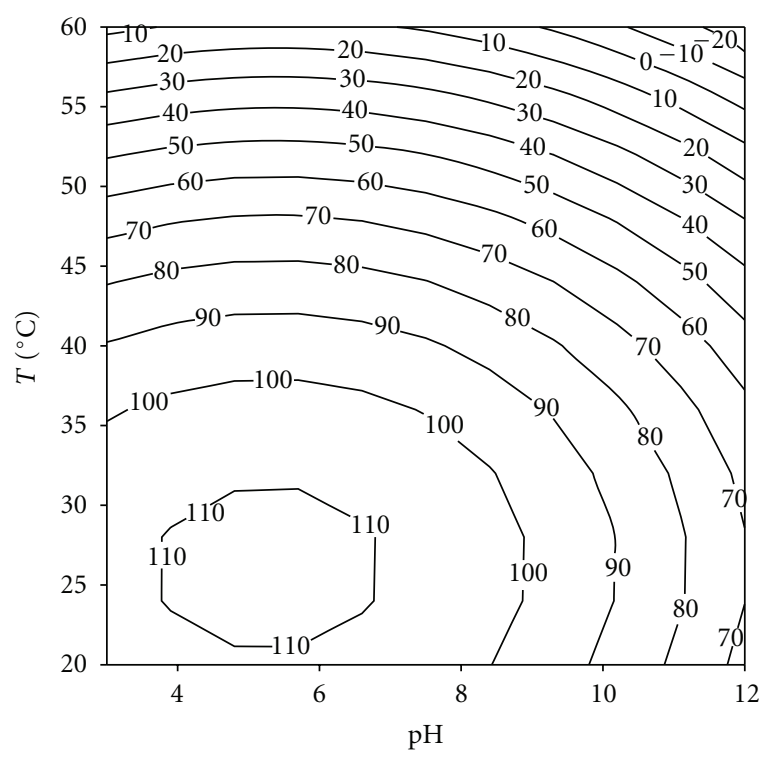

Figure 3: Response surface plot for the effect of $\mathrm{pH}$ and temperature on enzyme stability.

TABLE 1: Specific proteolytic activity $\left(\mathrm{U}_{\mathrm{C}} / \mathrm{mg}\right)$, keratinolytic activity $\left(\mathrm{U}_{\mathrm{K}} / \mathrm{mg}\right)$, and $\mathrm{K}: \mathrm{C}$ ratio of crude extract and commercial proteases.

\begin{tabular}{lccc}
\hline & $\begin{array}{c}\text { Proteolytic } \\
\text { activity } \\
\left(\mathrm{U}_{\mathrm{C}} / \mathrm{mg}\right)\end{array}$ & $\begin{array}{c}\text { Keratinolytic } \\
\text { activity } \\
\left(\mathrm{U}_{\mathrm{K}} / \mathrm{mg}\right)\end{array}$ & $\mathrm{K}: \mathrm{C}$ ratio \\
\hline Enzyme preparation & 15.67 & 159.3 & 10.17 \\
Proteinas K & 33.9 & 218.7 & 6.45 \\
Alcamax & 4.6 & 27.4 & 5.96 \\
Papain & 7.6 & 3.9 & 0.51 \\
\hline
\end{tabular}

after $2 \mathrm{~h}$ of incubation:

$$
\begin{aligned}
\text { (\%) R.A. : } & 91.33-18.12 * \mathrm{pH}-55.43 * T-18.83 \\
& * \mathrm{pH}^{2}-46.15 * T^{2}+0.72 * \mathrm{pH} * T,
\end{aligned}
$$

TABLe 2: Actual values (experimental data) and residual activity attained in Doehlert's design for $\mathrm{pH}$ and temperature stability.

\begin{tabular}{lccc}
\hline & $\mathrm{pH}$ & $\begin{array}{c}\text { Temperature }\left({ }^{\circ} \mathrm{C}\right) \\
\text { Experimental data }\end{array}$ & Residual activity $(\%)$ \\
\hline A & 7.5 & 40 & 93.4 \\
A & 7.5 & 40 & 89.1 \\
A & 7.5 & 40 & 92.2 \\
B & 12 & 40 & 45.1 \\
C & 9.75 & 60 & 3.25 \\
D & 5.25 & 60 & 4.5 \\
E & 3 & 40 & 104.4 \\
F & 5.25 & 20 & 106.4 \\
G & 9.75 & 20 & 104.4 \\
\hline
\end{tabular}

where $\mathrm{pH}$ and $T$ are given as codified data. The $r^{2}$ value was equal to 0.91 , indicating that only $9 \%$ of the total variation was not explained by the model. The contour graph of the proteolytic activity observed as a response to the interaction of $\mathrm{pH}$ versus temperature is shown in Figure 3. These results indicate that the enzyme is stable in a wide range of $\mathrm{pH}$ and temperatures, preserving more than $60 \%$ of its activity after $2 \mathrm{~h}$ of incubation at $\mathrm{pH} 11$ and $45^{\circ} \mathrm{C}$. A serine proteinase purified from P. lilacinus (Thom) Samson VKM F-3891 displayed $40 \%$ of residual activity after $3 \mathrm{~h}$ incubation at $60^{\circ} \mathrm{C}$ [29]. However, in other cases, such as the serine proteinase from Aspergillus chrysogenum, enzyme stability in the alkaline range is substantially reduced.

Studies on thermostability of the enzyme at 50,55 , and $60^{\circ} \mathrm{C}$ revealed that heat inactivation displays a typical first order kinetic (Figure 4(a)). The enzyme exhibited half lives of 62,29 , and $10 \mathrm{~min}$ at 50,55 , and $60^{\circ} \mathrm{C}$, respectively. Addition of metal ions such as $\mathrm{CaCl}_{2}$ and $\mathrm{MgCl}_{2}(5 \mathrm{mM})$ individually, improved the thermostability of the enzyme (Figures $4(\mathrm{~b})$ to $4(\mathrm{~d})$ ). It can be seen in Figure 4(b), the apparent half-life of the enzyme increased by 1.3-fold, 1.2fold, and 1.1-fold by the addition of $\mathrm{Mg}^{2+}, \mathrm{Ca}^{2+}$, and sorbitol, respectively. Similar results were observed at 55 and $60^{\circ} \mathrm{C}$ 


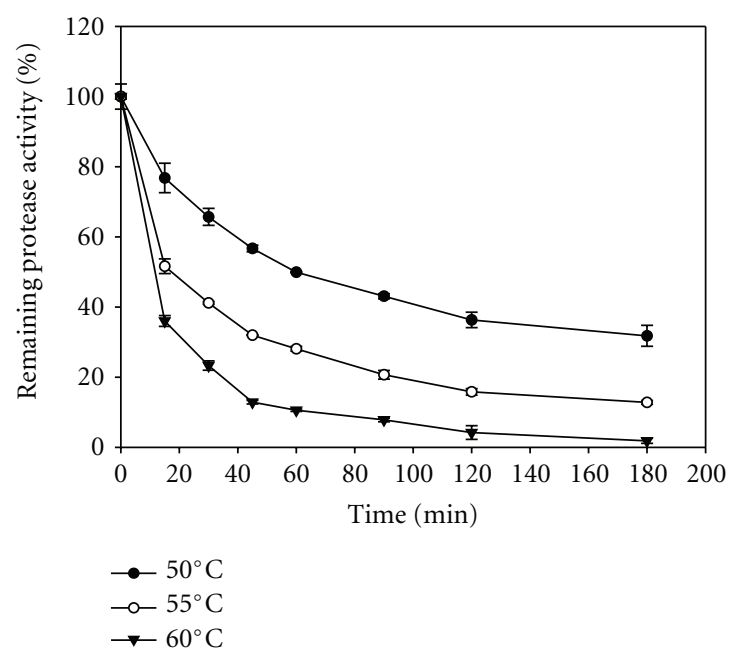

(a)

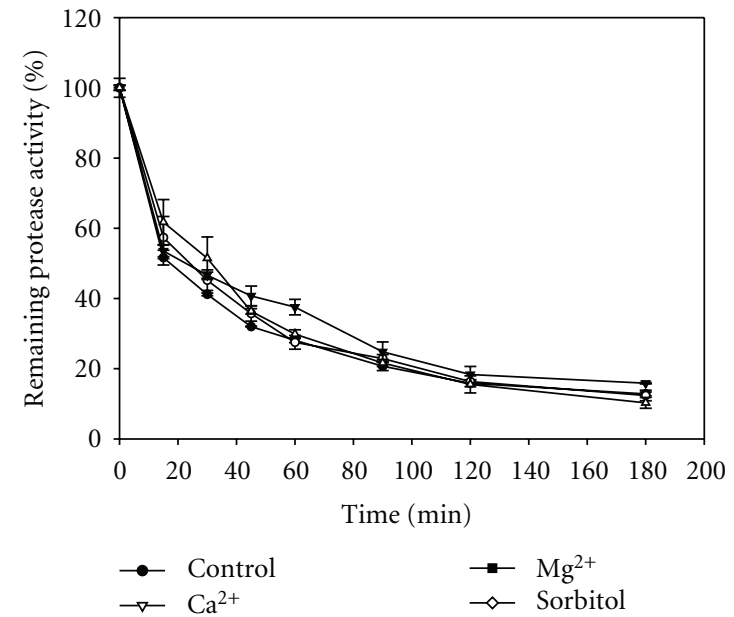

(c)

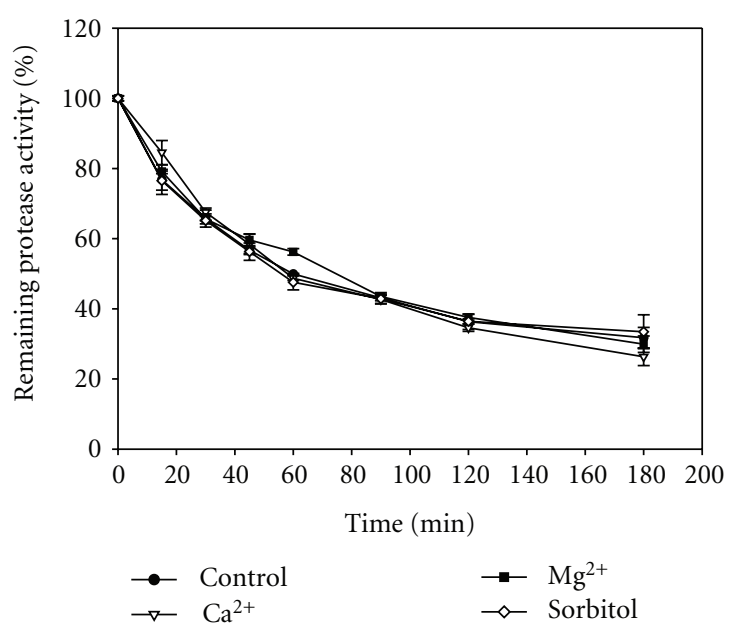

(b)

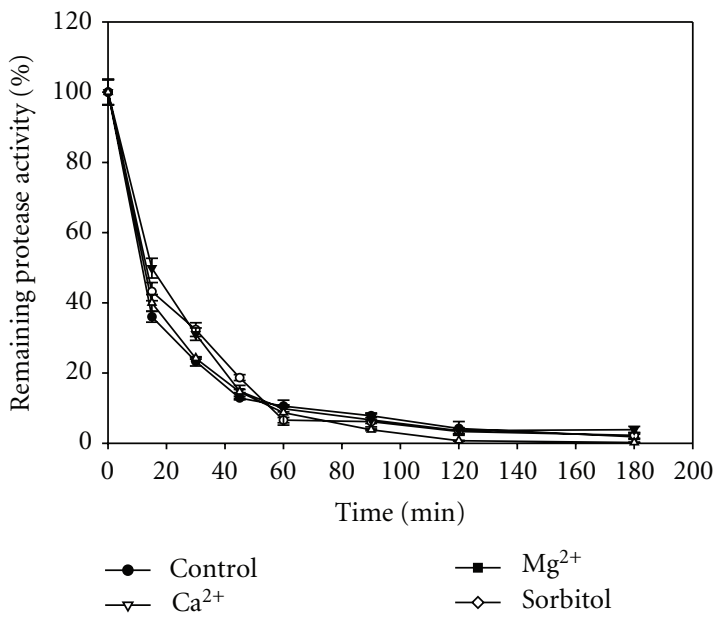

(d)

Figure 4: (a) Effect of temperature on protease stability $(\bullet) 50^{\circ} \mathrm{C} ;(\bigcirc) 55^{\circ} \mathrm{C} ;(\boldsymbol{\nabla}) 60^{\circ} \mathrm{C}$. (b) Effect of stabilizers on heat inactivation at $50^{\circ} \mathrm{C}$. (c) Effect of stabilizers on heat inactivation at $55^{\circ} \mathrm{C}$. (d) Effect of stabilizers on heat inactivation at $60^{\circ} \mathrm{C}$. For (b), (c), and (d) the original activity before preincubation was taken as $100 \%$. Values are means of three independent determinations.

where sorbitol increased half-life by 1.2 -fold. In the case of $\mathrm{Mg}^{2+}$, this metal increased the apparent half-life by 1.1fold and 1.3 fold at 55 and $60^{\circ} \mathrm{C}$, respectively. In general, all chemicals tested here produced a slight increase in the thermal stability of the enzyme.

It had been reported that the addition of $\mathrm{Ca}^{2+}$ or polyhydric alcohols, such as glycerol and polyethylene glycol caused an increase in thermal stability of alkaline proteases. The addition of sorbitol improved the thermal stability for an alkaline protease from $B$. cereus BG1, which increased its thermal stability by approximately 2 -fold at $60^{\circ} \mathrm{C}$ [30]. Kelkar and Deshpande [31] studied the influence of various polyols on the thermostability of pullulan-hydrolysing activity from Sclerotium rolfsii. The half-life of the enzyme activity at $60^{\circ} \mathrm{C}$ was about $30 \mathrm{~min}$, and in presence of xylitol and sorbitol $(3 \mathrm{M})$ they reported a significant enhancement in the thermostability of the enzyme with retention of $100 \%$ activity after incubation for $7 \mathrm{~h}$ at $60^{\circ} \mathrm{C}$. Ghorbel et al. [30] reported an alkaline protease that, in the presence of $10 \mathrm{mM}$ $\mathrm{Ca}^{2+}$, retained 100,93 , and $26 \%$ of its initial activity after heating for $15 \mathrm{~min}$ at 55,60 , and $70^{\circ} \mathrm{C}$, respectively. However, the enzyme was completely inactivated when incubated at $55^{\circ} \mathrm{C}$ for $15 \mathrm{~min}$ in the absence of calcium. On the contrary, the enzyme reported here in presence of $5 \mathrm{mM} \mathrm{Ca}^{2+}$ retained about 57 and $43 \%$ of its initial activity after heating $15 \mathrm{~min}$ at 55 and $60^{\circ} \mathrm{C}$, respectively, but the enzyme in absence of calcium retained more than $25 \%$ of its initial activity after $60 \mathrm{~min}$ of incubation at $55^{\circ} \mathrm{C}$.

Several reports showed that the addition of various additives such as polyols and PEG could enhance enzymes' thermal stability $[2,18]$. The increase in the thermal stability by adding these such as additives was probably due to the reinforcement of the hydrophobic interactions among nonpolar amino acids inside the enzyme molecules and thus 
TABle 3: Actual values (experimental data) and enzyme activity $\left(\mathrm{U}_{\mathrm{C}} \cdot \mathrm{mL}^{-1}\right)$ attained in Doehlert's design for the study of the effect of $\mathrm{pH}$ and Temperature on enzyme activity.

\begin{tabular}{|c|c|c|c|}
\hline & $\mathrm{pH}$ & Temperature $\left({ }^{\circ} \mathrm{C}\right)$ & $\mathrm{U}_{\mathrm{C}} \cdot \mathrm{mL}^{-1}$ \\
\hline & & ental data & \\
\hline $\bar{A}$ & 9 & 40 & 6.5 \\
\hline A & 9 & 40 & 6.4 \\
\hline A & 9 & 40 & 6.5 \\
\hline $\mathrm{B}$ & 12 & 40 & 6.6 \\
\hline $\mathrm{C}$ & 10.5 & 60 & 5 \\
\hline $\mathrm{D}$ & 7.5 & 60 & 11.6 \\
\hline $\mathrm{E}$ & 6 & 40 & 6 \\
\hline $\mathrm{F}$ & 7.5 & 20 & 1.2 \\
\hline G & 10.5 & 20 & 1.2 \\
\hline
\end{tabular}

increased their resistance to inactivation, since it had been reported that polyols modify the structure of water and/or strengthen hydrophobic interactions among nonpolar amino acids inside the protein molecules [32].

The effect of $\mathrm{Ca}^{2+}$ on the improvement of thermal stability against heat inactivation may be explained by the strengthening of interactions inside proteases molecules and by binding of this metal to the autolysis site. The activity of B. mojavensis protease was enhanced not only by $\mathrm{Ca}^{2+}$ but by $\mathrm{Fe}^{2+}$ and $\mathrm{Mn}^{2+}$. It is believed that metal ions protect the enzyme against thermal denaturation and play a vital role in maintaining the active conformation of the enzyme at higher temperatures [33].

3.4. Effect of $\mathrm{pH}$ and Temperature on Enzyme Activity. The $\mathrm{pH}$ and temperature values used in Doehlert's design for determination of the effect of $\mathrm{pH}$ and temperature on enzyme activity are given in Table 3.

The following regression equation was obtained to calculate the enzyme activity (E.A):

$$
\begin{aligned}
\mathrm{EA}\left(\mathrm{U} \cdot \mathrm{mL}^{-1}\right): & 6.48-0.928 * \mathrm{pH}+4.12 * T-0.188 \\
& * \mathrm{pH}^{2}-2.23 * T^{2}-3.835 * \mathrm{pH} * T,
\end{aligned}
$$

where $\mathrm{pH}$ and $T$ are given as codified data. The $r^{2}$ value was equal to 0.89 , indicating that only $11 \%$ of the total variation was not explained by the model. The contour graph of the keratinolytic activity observed as a response to the interaction of $\mathrm{pH}$ versus temperature is shown in Figure 5. These results indicate an optimal $\mathrm{pH}$ and temperature of 6.0 and $60^{\circ} \mathrm{C}$, respectively. Kotlova et al. [29] reported a thiol-dependent serine proteinase from $P$. lilacinus (Thom) Samson VKM F-3891 with an optimal pH into the alkaline range. Such $\mathrm{pH}$ dependence is also reported by Bonants et al. [34] for another proteinase isolated from a different strain of the fungus, P. lilacinus (Thom) Samson (CBS 143.75). These proteinases seem to belong to the subgroup of subtilisin-like enzymes with an optimum $\mathrm{pH}$ in the alkaline range $(\mathrm{pH} 10$ 12).

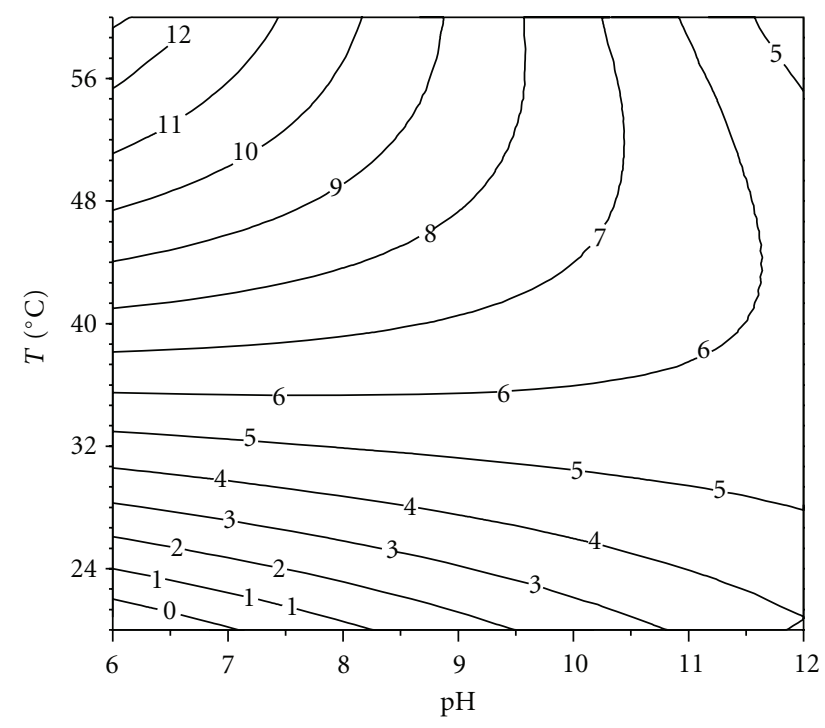

FIGURE 5: Response surface plot for the effect of $\mathrm{pH}$ and temperature on enzyme activity.

In our case, the protease present in the enzyme extract belongs to the group of enzymes, with an optimum $\mathrm{pH}$ in a neutral range ( $\mathrm{pH} 6-8)$ at an assay temperature of $60^{\circ} \mathrm{C}$. Although optimal temperature for keratin degradation is $60^{\circ} \mathrm{C}$, the stability of the enzyme under this condition is not so high. Because of that, a temperature of $55^{\circ} \mathrm{C}$, where the enzyme retains more than $90 \%$ of the optimal activity, is proposed for practical applications.

3.5. Effect of Protease Inhibitors, Metal Ions, and Organic Solvents on Enzyme Activity. The effect of various chemical reagents and metal ions on enzyme activity with azocasein as substrate is shown in Table 4 . The enzyme activity was strongly inhibited by PMSF (93\% of inhibition), a well-known inhibitor of serine proteinases, in particular subtilisins serine proteinases [35]. It was slightly inhibited by Pepstatin A but neither by iodoacetate, EDTA, nor by 1,10-Phenantroline. These facts suggest that in our case, the enzyme produced by $P$. lilacinus corresponds to a serine protease. Actually, most keratinases described until now are classified into this category [36]. The stability of the enzyme in presence of EDTA is advantageous for its use as a detergent additive. An enzyme, which is to be used as a detergent additive, should not have requirement for a metal cofactor. This is because detergent formulations contain high amounts of chelating agents, which specifically bind to and chelate metal ions making them unavailable in the detergent solution. The chelating agents remove the divalent cations responsible for water hardness and also assist in stain removal.

Among the metal ions tested, $\mathrm{Hg}^{2+}$ strongly inhibited proteolytic activity (94\% of inhibition), whereas $\mathrm{Ca}^{2+}$ and $\mathrm{Mg}^{2+}$ caused slight activation. $\mathrm{Hg}^{2+}$ is recognized as an oxidant agent of thiol-groups, and the enzyme inhibition by this ion suggests the presence of an important-SH group (such as free cysteine) at/or near the active site [37]. In 
TABLE 4: Effect of protease inhibitors, metal ions, detergents, and solvents on protease activity (data are given as Residual activity (\%) $\pm \mathrm{SD})$.

\begin{tabular}{|c|c|c|}
\hline Chemical none & Concentration & $\begin{array}{c}\text { Residual activity (\%) } \\
100\end{array}$ \\
\hline \multicolumn{3}{|l|}{ Inhibitor } \\
\hline PMSF & $2 \mathrm{mM}$ & $7.0 \pm 0.0$ \\
\hline Iodoacetate & $10 \mathrm{mM}$ & $95.1 \pm 4.7$ \\
\hline EDTA & $5 \mathrm{mM}$ & $99.6 \pm 6.3$ \\
\hline 1,10-Phenantroline & $1 \mathrm{mM}$ & $100 \pm 0.2$ \\
\hline Pepstatin A & $100 \mu \mathrm{g} / \mathrm{mL}$ & $87.5 \pm 5.5$ \\
\hline \multicolumn{3}{|l|}{ Metal ion } \\
\hline $\mathrm{Mg}^{2+}$ & $1 \mathrm{mM}$ & $105.0 \pm 1.2$ \\
\hline $\mathrm{Zn}^{2+}$ & $1 \mathrm{mM}$ & $92.8 \pm 1.4$ \\
\hline $\mathrm{Ca}^{2+}$ & $1 \mathrm{mM}$ & $102.9 \pm 0.5$ \\
\hline $\mathrm{Hg}^{2+}$ & $1 \mathrm{mM}$ & $6.0 \pm 0.6$ \\
\hline \multicolumn{3}{|l|}{ Detergents } \\
\hline Triton X-100 & $0.5 \%(\mathrm{v} / \mathrm{v})$ & $97.7 \pm 2.7$ \\
\hline Tween 20 & $0.5 \%(\mathrm{v} / \mathrm{v})$ & $98.5 \pm 2.0$ \\
\hline SDS & $0.5 \%(\mathrm{v} / \mathrm{v})$ & $75.9 \pm 3.4$ \\
\hline \multicolumn{3}{|l|}{ Bleaching agent } \\
\hline \multirow{3}{*}{$\mathrm{H}_{2} \mathrm{O}_{2}$} & $1 \%(\mathrm{w} / \mathrm{v})$ & $140 \pm 2.3$ \\
\hline & $2 \%$ & $137 \pm 0.3$ \\
\hline & $3 \%$ & $122.7 \pm 4.0$ \\
\hline \multirow{3}{*}{ Sodium perborate } & $0.2 \%(\mathrm{w} / \mathrm{v})$ & $99.7 \pm 2.4$ \\
\hline & $0.5 \%$ & $97.6 \pm 0.9$ \\
\hline & $1.0 \%$ & $90.8 \pm 2.0$ \\
\hline \multicolumn{3}{|l|}{ Solvent } \\
\hline DMSO & $1 \%(\mathrm{v} / \mathrm{v})$ & $106.0 \pm 1.6$ \\
\hline Ethanol & $1 \%(\mathrm{v} / \mathrm{v})$ & $105.4 \pm 4.0$ \\
\hline Methanol & $1 \%(\mathrm{v} / \mathrm{v})$ & $117.0 \pm 2.9$ \\
\hline Isopropanol & $1 \%(\mathrm{v} / \mathrm{v})$ & $98.9 \pm 1.7$ \\
\hline
\end{tabular}

addition, the strong inactivation by $\mathrm{Hg}^{2+}$ is typical for proteinases belonging to the thermitase and proteinase $\mathrm{K}$ subgroups [38]. This feature makes our P. lilacinus keratinase substantially different to the true bacillary subtilisins, as well as to the serine proteinase from $P$. lilacinus isolated by Bonants et al. [34], which is not inactivated by $\mathrm{Hg}^{2+}$. Based on the presence of functionally important sulfhydryl groups, our keratinase resembles proteinase $\mathrm{K}$ and bacillary thioldependent subtilisins much more than other fungal serine proteases.

Divalent metal ions such as $\mathrm{Ca}^{2+}$ and $\mathrm{Mg}^{2+}$ slightly activated the enzyme. This fact could be explained because of that they could act as salt or ions bridges stabilizing the enzyme under its active conformation, and thus they might protect the enzyme against thermal denaturation $[39,40]$.

Crude enzyme preparation showed to be highly stable in presence of different organic solvents such as DMSO, ethanol, methanol, and isopropanol (Table 4), a positive fact considering the potential practical application.
3.6. Effect of Surfactants and Bleaching Agents on Enzyme Stability. The above-mentioned characteristics of our $P$. lilacinus protease suggested its potential use in different applications like laundry detergent formulation. In order to be effective during washing, a good detergent protease must be compatible and stable with all commonly used detergent compounds such as surfactants, bleaching agents, and other additives, which might be present in detergent formulation [1]. In our case, a crude protease extract was incubated $60 \mathrm{~min}$ at room temperature in presence of several additives, and then the residual protease activity was assayed under standard conditions.

As can be seen in Table 4, crude protease was highly stable in presence of nonionic surfactants. It retained near $100 \%$ of its initial activity in presence of $0.5 \%$ Triton X100 and $0.5 \%$ Tween 20 . In presence of $0.5 \%$ of SDS, a strong anionic surfactant, it exhibited moderated stability (75\%) after $1 \mathrm{~h}$ of incubation. SDS is known to be a strong denaturant of proteins including alkaline proteases. It could unfold most proteins through the interaction between the charged head group of SDS and the positively charged amino acid side chains of proteins and between the alkyl chain of SDS and the nonpolar parts on the surface as well as in the interior of proteins [41]. The retention of protease activity by our enzyme preparation in presence of SDS was higher than that of a protease from Aspergillus clavatus ES1, which retained only $33 \%$ of its activity under the same stability assay conditions [42].

On the other hand, our enzyme preparation showed excellent stability toward bleaching agents such as $\mathrm{H}_{2} \mathrm{O}_{2}$ and sodium perborate (Table 4 ). It showed an stability similar to proteases from $B$. licheniformis $\mathrm{NH1}$, which retained $85 \%$ and $80 \%$ of its activity after incubation with $0.5 \% \mathrm{H}_{2} \mathrm{O}_{2}$ [19] and resulted in being more stable than an alkaline protease from B. licheniformis RP1 [43] which is less stable against bleaching agents; it's just retained $68 \%$ and $48 \%$ of its activity after $1 \mathrm{~h}$ incubation at $40^{\circ} \mathrm{C}$ in presence of $2 \% \mathrm{H}_{2} \mathrm{O}_{2}$ and $0.2 \%$ sodium perborate, respectively. Bleaching agents inactivate proteins oxidatively, being Met the primary site for oxidative inactivation. All subtilisins contain a Met residue next to the catalytic Ser residue, so that many of them tend to undergo oxidative inactivation in presence of a bleaching agent such as hydrogen peroxide. Thus, many of available alkaline proteases exhibited low activity and stability toward oxidants, which are common ingredients in modern bleachbased detergents. To overcome these shortcomings, several attempts have been made to enhance enzyme stability by protein engineering [44]. That is why it is important to obtain enzymes with high stability against surfactants and oxidants for practical applications. Detergent applications for keratinases have been also suggested [36]. These include removal of keratinous dirt that are often encountered in the laundry, such as collar of shirts and used as additives for cleaning up drains clogged with keratinous waste.

3.7. Detergent Compatibility. All the commercial detergents contain hydrolytic enzymes, and these enzymes-based detergents known as "green chemicals" find a wide range of 


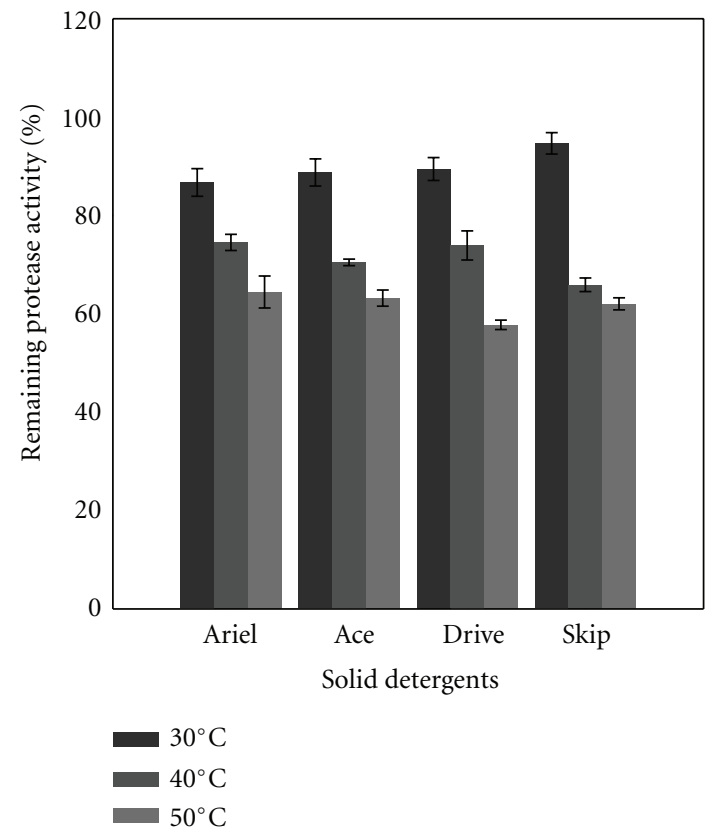

(a)

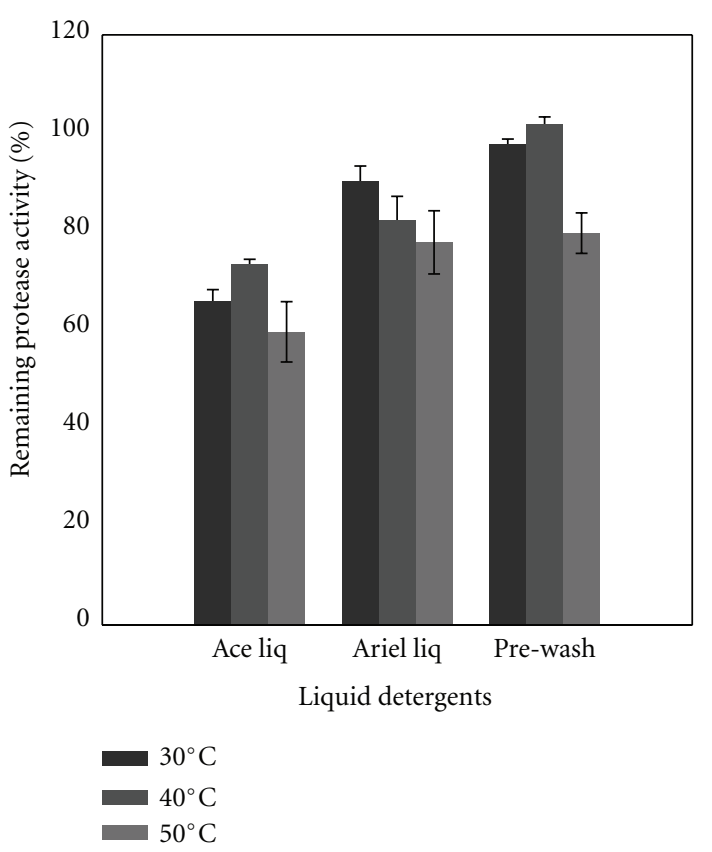

(b)

FIGURE 6: Stability of the crude enzyme in the presence of various commercial solid (a) and liquid detergents (b). CE was incubated in each detergent mentioned for $1 \mathrm{~h}$ at different temperatures $\left(30-50^{\circ} \mathrm{C}\right)$, and the remaining activities were determined under standard conditions. The enzyme activity of a control, incubated under similar conditions without detergent, was taken as $100 \%$.

applications in laundry, dishwashing, textile, and other related industries [45].

In order to check the compatibility with liquid and solid detergents, the crude enzyme was preincubated in presence of various commercial laundry detergents for $1 \mathrm{~h}$ at 30,40, and $50^{\circ} \mathrm{C}$. Solid detergents were diluted in tap water to a final concentration of $7 \mathrm{mg} / \mathrm{mL}$, and the liquid ones were diluted 100 -fold to simulate washing conditions. As can be seen in Figure 6(a) the crude enzyme was very stable towards all solid detergents tested, even at $50^{\circ} \mathrm{C}$ after $1 \mathrm{~h}$ of incubation, it retained more than $60 \%$ of its activity in presence of Ariel, Ace, and Skip. In presence of Drive, it retained about 57\% of its activity being more stable than an alkaline protease from Vibrio fluvialis strain VM10 reported by Venugopal and Saramma [46], which retained just $42 \%$ of its activity in presence of Ariel as well as an alkaline serine protease from Bacillus sp. SSR1 reported by Singh et al. [47] which retain lees than $40 \%$ of its activity after $1 \mathrm{~h}$ of incubation in presence of Ariel at $40^{\circ} \mathrm{C}$. Interestingly, it was more stable than the commercial protease named Maxacal, which retained less than $60 \%$ after $1 \mathrm{~h}$ of incubation in presence of Ariel at $40^{\circ} \mathrm{C}$ [47]. Similarly, proteases from B. mojavensis A21 [48] and from $B$. licheniformis RP1 [43] are shown to retain more than 40 and $80 \%$ of their activity in presence of Dixan after $1 \mathrm{~h}$ of incubation at $50^{\circ} \mathrm{C}$, respectively.

In presence of liquid detergents, the crude enzyme retained more than $75 \%$ and $50 \%$ of its initial activity in presence of Ariel and Ace, respectively, after $1 \mathrm{~h}$ of incubation at $50^{\circ} \mathrm{C}$ (Figure 6(b)).
From the results presented here about the compatibility and stability whit commercial detergents at different temperatures, it can be concluded that our protease will be more effective at temperature from 30 to $40^{\circ} \mathrm{C}$ for long washing cycles $(60 \mathrm{~min})$ and at $50^{\circ} \mathrm{C}$ for short washing cycles $(10-$ $30 \mathrm{~min}$ ). But with Ariel liq. long washing cycles could be done at $55^{\circ} \mathrm{C}$ too, because it retained about $78 \%$ of its original stability.

3.8. Wash Performance Analysis. The wash performances of the protease present in the crude extract were assessed by its ability to remove blood stain from white cotton cloth (Figure 7). Enzyme in combination of the commercial detergent Skip was tried. The visual comparison of the washed cloth revealed that washing with distilled water at temperatures of 30 and $40^{\circ} \mathrm{C}$ removed some amount of blood stain from the cotton cloth (Figures $7(\mathrm{a}), 7(\mathrm{~d})$, $7(\mathrm{~g})$, and $7(\mathrm{j}))$. As can be seen, the replacement of the enzymes present in the commercial detergent by the crude enzyme gave a complete blood stain elimination at both temperatures and times, such as the endogenous enzymes from the commercial detergent has done (Figures 7(c), 7(f), $7(\mathrm{i}), 7(\mathrm{l}))$. These results show the efficiency of $P$. lilacinus protease in proteinaceous stain removal efficiency.

Abidi et al. [49] showed also the significant improvement of the supplementation of proteolytic preparation of Botrytis cinerea, in a laundry detergent (Henkel-Alki), in the elimination of blood, egg yolk, and chocolate stains on fabric. Jellouli et al. [50] and Savitha et al. [51] reported similar results in 


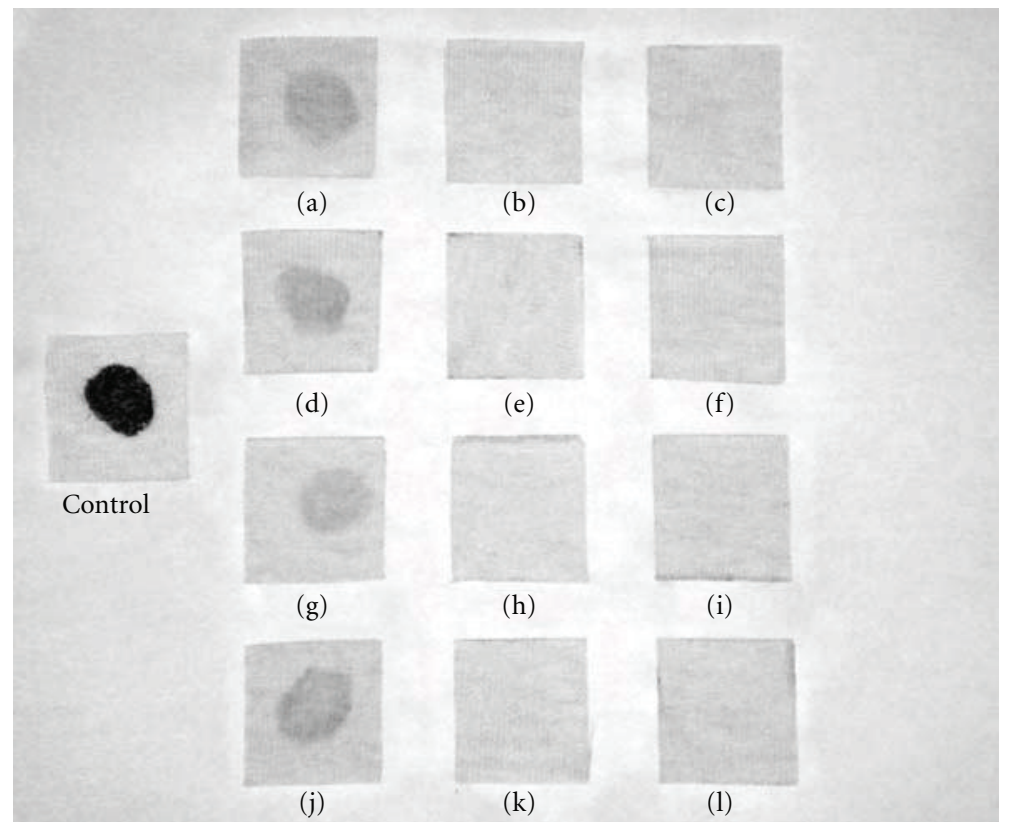

FIGURE 7: Washing performance analysis of the P. lilacinus enzyme preparation in the presence of the commercial detergent Skip. Analysis were done at $30^{\circ} \mathrm{C}((\mathrm{a})-(\mathrm{f}))$ and $40^{\circ} \mathrm{C}((\mathrm{g})-(\mathrm{l}))$, for $30 \mathrm{~m}((\mathrm{a})-(\mathrm{c})$ and $(\mathrm{g})-(\mathrm{i}))$ and $60 \mathrm{~m}((\mathrm{~d})-(\mathrm{f})$ and $(\mathrm{j})-(\mathrm{l}))$. Cloth washed with tap water ((a), (d), (g), and (j)); ((b), (e), (h), and (k)) cloth washed with Skip; ((c), (f), (i), and (l)) cloth washed with Skip added with crude enzyme of the P. lilacinus protease.

their wash performance tests. Therefore, P. lilacinus crude extracts containing protease activity could be considered as a potential candidate for use as cleaning additive in detergents to facilitate the release of proteinaceous stains.

\section{Conclusions}

A locally isolated $P$. lilacinus strain produces an extracellular protease with keratinase activity when grown on hair waste, the main solid-wastes produced in tanneries, as substrate in submerged cultures.

The protease was characterized, and it exhibited remarkable stability toward surfactants, bleaching agents, and detergent additives like EDTA and sodium perborate. This property of the enzyme is very essential for its application as detergent additive. Our study shows that the extracellular proteolytic enzyme produced by this strain could have an industrial application in detergent industries. Moreover, the enzyme was compatible with most of the laundry detergents tested and showed a good washing performance.

\section{Acknowledgment}

This research work was supported by CONICET (Argentina National Council of Scientific and Technical Research).

\section{References}

[1] R. Gupta, Q. Beg, and P. Lorenz, "Bacterial alkaline proteases: molecular approaches and industrial applications," Applied Microbiology and Biotechnology, vol. 59, no. 1, pp. 15-32, 2002.
[2] M. B. Rao, A. M. Tanksale, M. S. Ghatge, and V. V. Deshpande, "Molecular and biotechnological aspects of microbial proteases," Microbiology and Molecular Biology Reviews, vol. 62, no. 3, pp. 597-635, 1998.

[3] K. Tsuchiya, Y. Nakamura, H. Sakashita, and T. Kimura, "Purification and characterization of a thermostable alkaline protease from alkalophilic Thermoactinomyces sp. HS 682," Bioscience, Biotechnology, and Biochemistry, vol. 56, no. 2, pp. 246-250, 1992.

[4] A. M. Wolff, M. S. Showell, M. G. Venegas et al., "Laundry performance of subtilisin proteases," in Subtilisin Enzymes: Practical Protein Engineering, R. Bott and C. Betzel, Eds., pp. 113-120, Springer, New York, NY, USA, 1996.

[5] D. A. D. Parry and A. C. T. North, "Hard $\alpha$-keratin intermediate filament chains: substructure of the $\mathrm{N}$-and C-terminal domains and the predicted structure and function of the Cterminal domains of type I and type II chains," Journal of Structural Biology, vol. 122, no. 1-2, pp. 67-75, 1998.

[6] B. C. Galarza, I. Cavello, C. A. Greco, R. Hours, M. M. Schuldt, and C. S. Cantera, "Alternative technologies for adding value to bovine hair waste," Journal of the Society of Leather Technologies and Chemists, vol. 94, no. 1, pp. 26-32, 2010.

[7] I. Cavello, S. Cavalitto, and R. Hours, "Biodegradation of a keratin waste and the concomitant production of detergent stable serine proteases from Paecilomyces lilacinus," Applied Biochemistry and Biotechnology, vol. 167, no. 5, pp. 945-958, 2012.

[8] S. Sangali and A. Brandelli, "Isolation and characterization of a novel feather-degrading bacterial strain," Applied Biochemistry and Biotechnology A, vol. 87, no. 1, pp. 17-24, 2000.

[9] B. C. Galarza, L. M. Goya, C. S. Cantera, M. L. Garro, H. E. Reinos, and L. M. I. López, "Fungal biotransformation of bovine hair part 1: isolation of fungus with keratinolytic 
activity," Journal of the Society of Leather Technologies and Chemists, vol. 88, no. 3, pp. 93-98, 2004.

[10] M. M. Bradford, "A rapid and sensitive method for the quantitation of microgram quantities of protein utilizing the principle of protein dye binding," Analytical Biochemistry, vol. 72, no. 1-2, pp. 248-254, 1976.

[11] C. Liggieri, M. C. Arribére, S. A. Trejo, F. Canals, F. X. Avilés, and N. S. Priolo, "Purification and biochemical characterization of asclepain c I from the latex of Asclepias curassavica L.," Protein Journal, vol. 23, no. 6, pp. 403-411, 2004.

[12] A. Riffel, F. Lucas, P. Heeb, and A. Brandelli, "Characterization of a new keratinolytic bacterium that completely degrades native feather keratin," Archives of Microbiology, vol. 179, no. 4, pp. 258-265, 2003.

[13] S. G. Joshi, M. M. Tejashwini, N. Revati et al., "Isolation, identification and characterization of a feather degrading bacterium," International Journal of Poultry Science, vol. 6, no. 9, pp. 689-693, 2007.

[14] H. Gradišar, J. Friedrich, I. Krizaj et al., "Similarities and specificities of fungal keratinolytic proteases: comparison of keratinases of paecilomyces marquandii and doratomyces microsporus to some known proteases," Applied and Environmental Microbiology, vol. 71, no. 7, pp. 3420-3426, 2005.

[15] S. Sangali and A. Brandelli, "Feather keratin hydrolysis by a Vibrio sp. strain kr2," Journal of Applied Microbiology, vol. 89, no. 5, pp. 735-743, 2000.

[16] A. P. F. Corrêa, D. J. Daroit, and A. Brandelli, "Characterization of a keratinase produced by Bacillus sp. P7 isolated from an Amazonian environment," International Biodeterioration and Biodegradation, vol. 64, no. 1, pp. 1-6, 2010.

[17] S. F. Cavalitto and C. F. Mignone, "Application of factorial and Doehlert designs for optimization of protopectinase production by a Geotrichum klebahnii strain," Process Biochemistry, vol. 42, no. 2, pp. 175-179, 2007.

[18] A. Haddar, A. Sellami-Kamoun, N. Fakhfakh-Zouari, N. Hmidet, and M. Nasri, "Characterization of detergent stable and feather degrading serine proteases from Bacillus mojavensis A21," Biochemical Engineering Journal, vol. 51, no. 1-2, pp. 53-63, 2010.

[19] N. Hmidet, N. El-Hadj Ali, A. Haddar, S. Kanoun, S. K. Alya, and M. Nasri, "Alkaline proteases and thermostable $\alpha$-amylase co-produced by Bacillus licheniformis NH1: characterization and potential application as detergent additive," Biochemical Engineering Journal, vol. 47, no. 1-3, pp. 71-79, 2009.

[20] K. Wawrzkiewicz, T. Wolski, and J. Łobarzewski, "Screening the keratinolytic activity of dermatophytes in vitro," Mycopathologia, vol. 114, no. 1, pp. 1-8, 1991.

[21] A. Riffel and A. Brandelli, "Keratinolytic bacteria isolated from feather waste," Brazilian Journal of Microbiology, vol. 37, no. 3, pp. 395-399, 2006.

[22] T. Korniłłowicz-Kowalska and J. Bohacz, "Biodegradation of keratin waste: theory and practical aspects," Waste Management, vol. 31, no. 8, pp. 1689-1701, 2011.

[23] R. Sharma and R. Gupta, "Thermostable, thiol activated keratinases from Pseudomonas aeruginosa KS-1 for prospective application in prion decontamination," Research Journal of Microbiology, vol. 5, no. 10, pp. 954-965, 2010.

[24] S. Yamamura, Y. Morita, Q. Hasan, K. Yokoyama, and E. Tamiya, "Keratin degradation: a cooperative action of two enzymes from Stenotrophomonas sp.," Biochemical and Biophysical Research Communications, vol. 294, no. 5, pp. 1138-1143, 2002.

[25] S. W. Cheng, H. M. Hu, S. W. Shen, H. Takagi, M. Asano, and Y. C. Tsai, "Production and characterization of keratinase of a feather-degrading Bacillus licheniformis PWD-1," Bioscience, Biotechnology, and Biochemistry, vol. 59, no. 12, pp. 22392243, 1995.

[26] H. Takami, T. Akiba, and K. Horikoshi, "Production of extremely thermostable alkaline protease from Bacillus sp. no. AH-101," Applied Microbiology and Biotechnology, vol. 30, no. 2, pp. 120-124, 1989.

[27] S. H. Bhosale, M. B. Rao, V. V. Deshpande, and M. C. Srinivasan, "Thermostability of high-activity alkaline protease from Conidiobolus coronatus (NCL 86.8.20)," Enzyme and Microbial Technology, vol. 17, no. 2, pp. 136-139, 1995.

[28] U. C. Banerjee, R. K. Sani, W. Azmi, and R. Soni, "Thermostable alkaline protease from Bacillus brevis and its characterization as a laundry detergent additive," Process Biochemistry, vol. 35, no. 1-2, pp. 213-219, 1999.

[29] E. K. Kotlova, N. M. Ivanova, M. P. Yusupova, T. L. Voyushina, N. E. Ivanushkina, and G. G. Chestukhina, "Thiol-dependent serine proteinase from Paecilomyces lilacinus: purification and catalytic properties," Biochemistry, vol. 72, no. 1, pp. 117-123, 2007.

[30] B. Ghorbel, A. Sellami-Kamoun, and M. Nasri, "Stability studies of protease from Bacillus cereus BG1," Enzyme and Microbial Technology, vol. 32, no. 5, pp. 513-518, 2003.

[31] H. S. Kelkar and M. V. Deshpande, "Effect of polyols on the thermostability of pullulan-hydrolysing activity from Sclerotium rolfsii," Biotechnology Letters, vol. 13, no. 12, pp. 901-906, 1991.

[32] J. F. Back, D. Oakenfull, and M. B. Smith, "Increased thermal stability of proteins in the presence of sugars and polyols," Biochemistry, vol. 18, no. 23, pp. 5191-5196, 1979.

[33] D. R. Durham, D. B. Stewart, and E. J. Stellwag, "Novel alkaline- and heat-stable serine proteases from alkalophilic Bacillus sp. strain GX6638," Journal of Bacteriology, vol. 169, no. 6, pp. 2762-2768, 1987.

[34] P. J. M. Bonants, P. F. L. Fitters, H. Thijs, E. den Belder, C. Waalwijk, and J. W. D. M. Henfling, "A basic serine protease from Paecilomyces lilacinus with biological activity against Meloidogyne hapla eggs," Microbiology, vol. 141, no. 4, pp. 775784, 1995.

[35] R. J. Siezen and J. A. M. Leunissen, "Subtilases: the superfamily of subtilisin-like serine proteases," Protein Science, vol. 6, no. 3, pp. 501-523, 1997.

[36] R. Gupta and P. Ramnani, "Microbial keratinases and their prospective applications: an overview," Applied Microbiology and Biotechnology, vol. 70, no. 1, pp. 21-33, 2006.

[37] D. J. Daroit, A. Simonetti, P. F. Hertz, and A. Brandelli, "Purification and characterization of an extracellular $\beta$ glucosidase from Monascus purpureus," Journal of Microbiology and Biotechnology, vol. 18, no. 5, pp. 933-941, 2008.

[38] M. Ballinger and J. A. Wells, "Subtilisin," in Handbook of Proteases, A. Barrett, N. D. Rawlings, and J. F. Woessner, Eds., pp. 289-294, 1998.

[39] S. Balaji, M. S. Kumar, R. Karthikeyan et al., "Purification and characterization of an extracellular keratinase from a hornmeal-degrading Bacillus subtilis MTCC (9102)," World Journal of Microbiology and Biotechnology, vol. 24, no. 11, pp. 2741-2745, 2008.

[40] R. Sareen and P. Mishra, "Purification and characterization of organic solvent stable protease from Bacillus licheniformis RSP-09-37," Applied Microbiology and Biotechnology, vol. 79, no. 3, pp. 399-405, 2008.

[41] D. E. Otzen, "Protein unfolding in detergents: effect of micelle structure, ionic strength, $\mathrm{pH}$, and temperature," Biophysical Journal, vol. 83, no. 4, pp. 2219-2230, 2002. 
[42] M. Hajji, S. Kanoun, M. Nasri, and N. Gharsallah, "Purification and characterization of an alkaline serine-protease produced by a new isolated Aspergillus clavatus ES1," Process Biochemistry, vol. 42, no. 5, pp. 791-797, 2007.

[43] A. Sellami-Kamoun, A. Haddar, N. E. H. Ali, B. GhorbelFrikha, S. Kanoun, and M. Nasri, "Stability of thermostable alkaline protease from Bacillus licheniformis RP1 in commercial solid laundry detergent formulations," Microbiological Research, vol. 163, no. 3, pp. 299-306, 2008.

[44] D. A. Estell, T. P. Graycar, and J. A. Wells, "Engineering an enzyme by site-directed mutagenesis to be resistant to chemical oxidation," The Journal of Biological Chemistry, vol. 260, no. 11, pp. 6518-6521, 1985.

[45] A. K. Mukherjee, M. Borah, and S. K. Rai, "To study the influence of different components of fermentable substrates on induction of extracellular $\alpha$-amylase synthesis by Bacillus subtilis DM-03 in solid-state fermentation and exploration of feasibility for inclusion of $\alpha$-amylase in laundry detergent formulations," Biochemical Engineering Journal, vol. 43, no. 2, pp. 149-156, 2009.

[46] M. Venugopal and A. V. Saramma, "Characterization of alkaline protease from Vibrio fluvialis strain VM10 isolated from a mangrove sediment sample and its application as a laundry detergent additive," Process Biochemistry, vol. 41, no. 6, pp. 1239-1243, 2006.

[47] J. Singh, N. Batra, and R. C. Sobti, "Serine alkaline protease from a newly isolated Bacillus sp. SSR1," Process Biochemistry, vol. 36, no. 8-9, pp. 781-785, 2001.

[48] N. Fakhfakh-Zouari, A. Haddar, N. Hmidet, F. Frikha, and M. Nasri, "Application of statistical experimental design for optimization of keratinases production by Bacillus pumilus A1 grown on chicken feather and some biochemical properties," Process Biochemistry, vol. 45, no. 5, pp. 617-626, 2010.

[49] F. Abidi, F. Limam, and M. M. Nejib, "Production of alkaline proteases by Botrytis cinerea using economic raw materials: assay as biodetergent," Process Biochemistry, vol. 43, no. 11, pp. 1202-1208, 2008.

[50] K. Jellouli, O. Ghorbel-Bellaaj, H. B. Ayed, L. Manni, R. Agrebi, and M. Nasri, "Alkaline-protease from Bacillus licheniformis MP1: purification, characterization and potential application as a detergent additive and for shrimp waste deproteinization," Process Biochemistry, vol. 46, no. 6, pp. 1248-1256, 2011.

[51] S. Savitha, S. Sadhasivam, K. Swaminathan, and F. H. Lin, "Fungal protease: production, purification and compatibility with laundry detergents and their wash performance," Journal of the Taiwan Institute of Chemical Engineers, vol. 42, no. 2, pp. 298-304, 2011. 

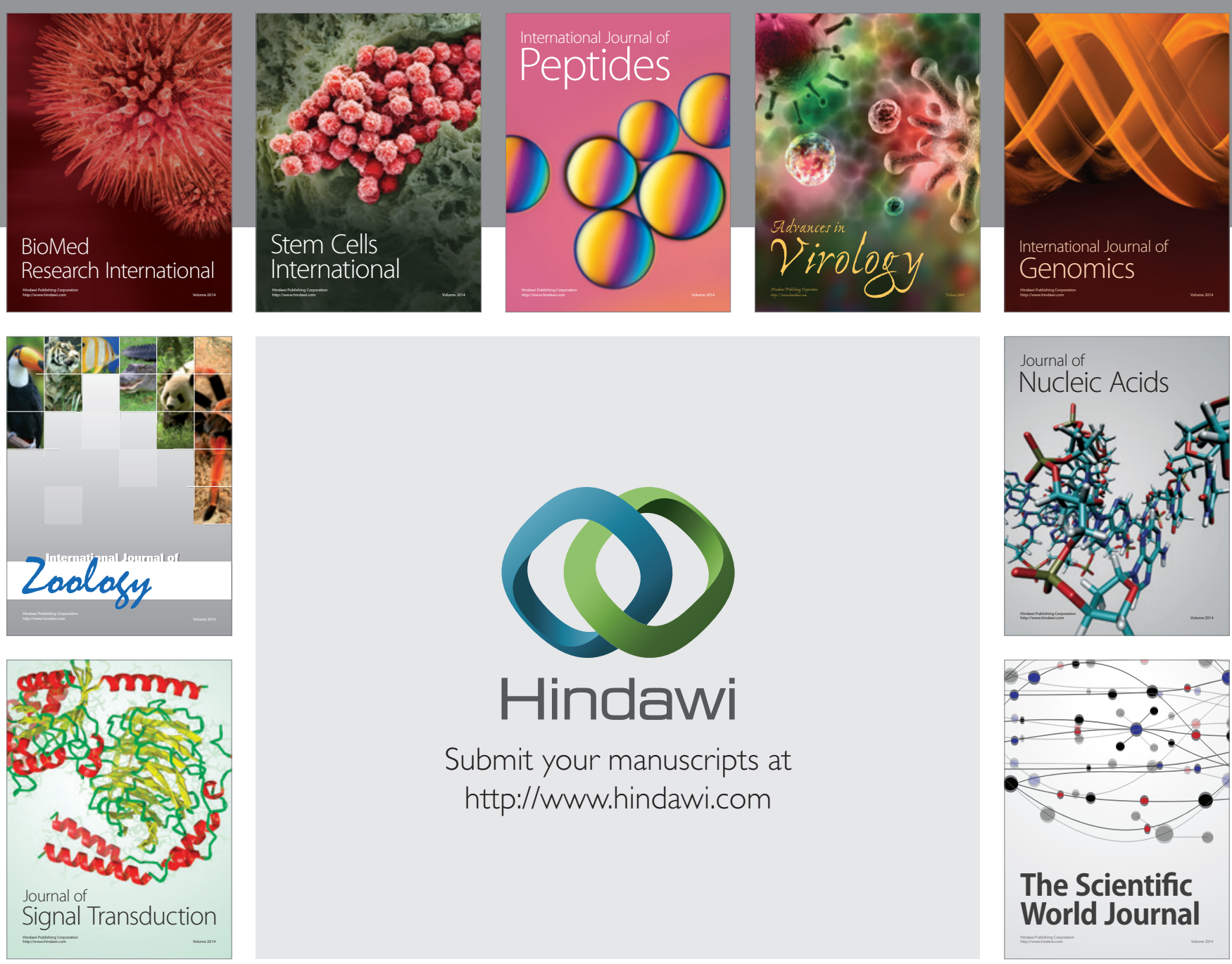

Submit your manuscripts at

http://www.hindawi.com
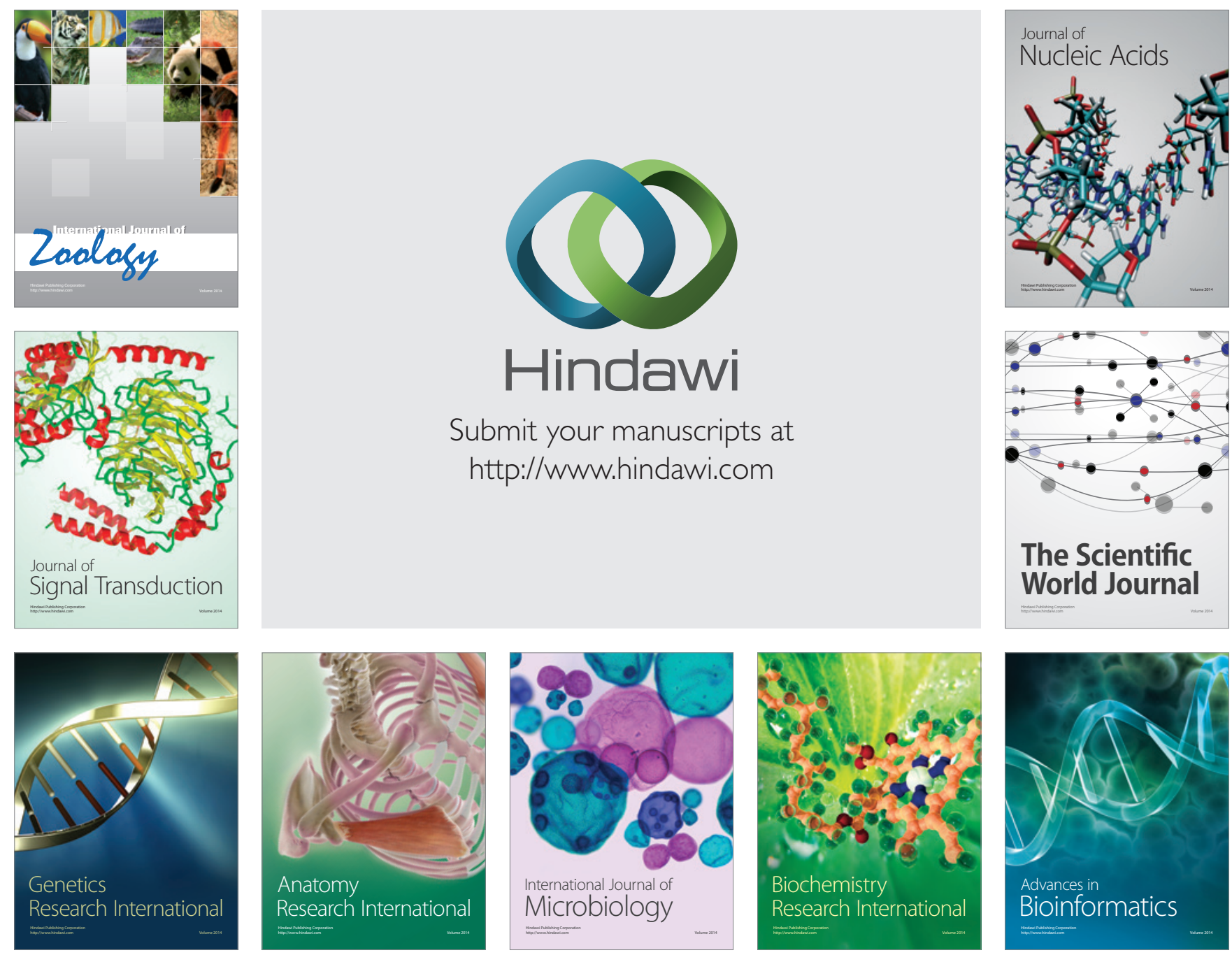

The Scientific World Journal
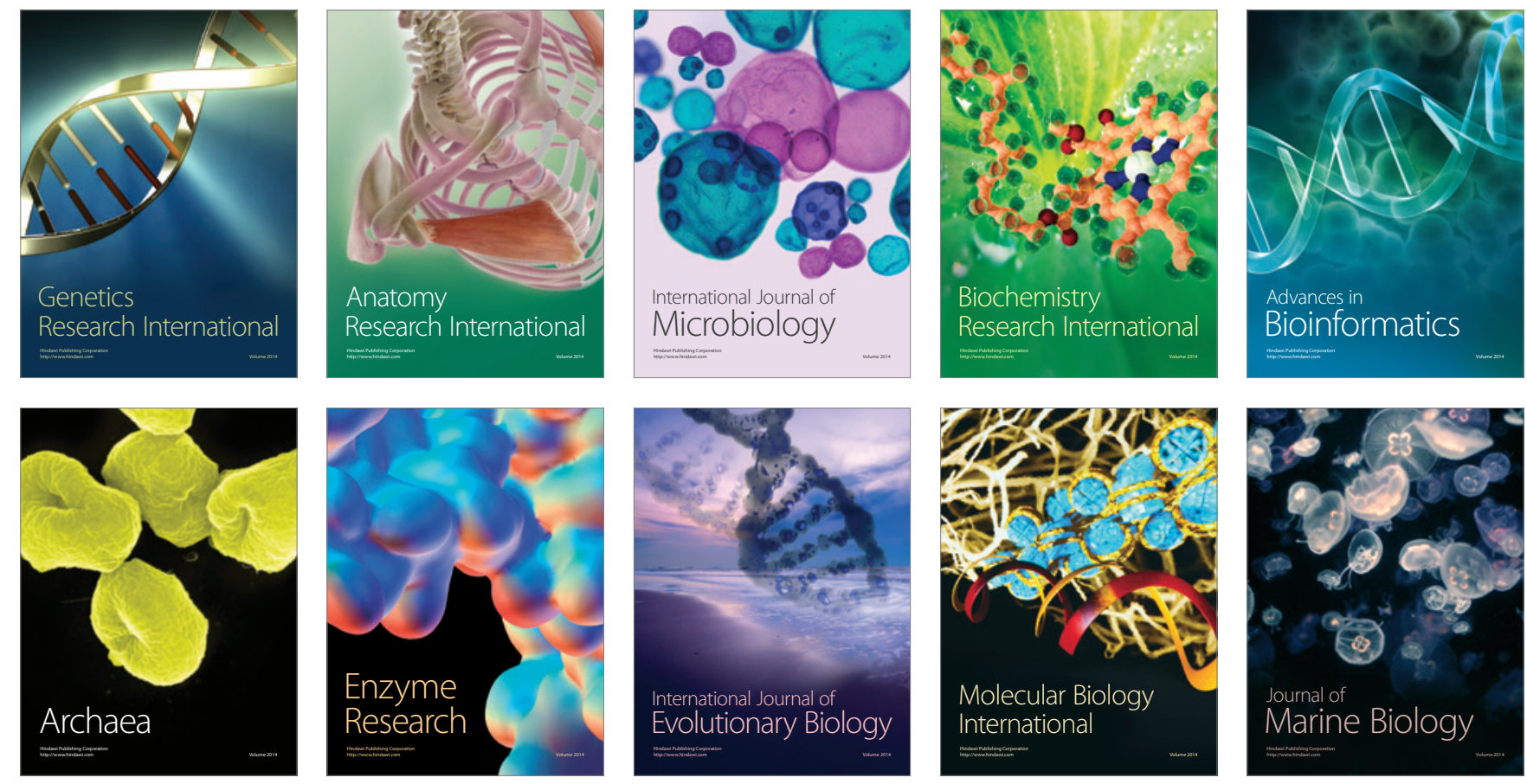